\title{
Corporate Social Responsibility Disclosure (A Comparison between Islamic and Conventional Financial Institutions in Bahawalpur Region)
}

\author{
Muhammad Taimoor Hassan \\ Lecturer, Department Of Management Sciences, The Islamia University of Bahawalpur, \\ Pakistan \\ Ambreen Kausar, Huma Ashiq, Hefza Inam, Humara Nasar, Rabia Amjad \\ Department Of Management Sciences, The Islamia University of Bahawalpur, Pakistan.

\section{Muhammad Arfan Lodhi} \\ Training Advisor, Human Resource Management Academic Research Society \\ PhD Scholar \& Visiting Lecturer, The Islamia University of Bahawalpur, Pakistan \\ E-mail: Samaritan_as@hotmail.com
}

Accepted: January 17, 2012 Published: March 17, 2012

Doi:10.5296/ijld.v2i1.1524ＵRL: http://dx.doi.org/10.5296/ijld.v2i1.1524

\begin{abstract}
Purpose:-The purpose of this paper is to compare the Corporate Social Responsibility practices in Islamic and Conventional banking. And the working of CSR in both IFIs and CFIs or either both institution work on same pattern.

Design/methodology/approach: - By using content analysis approach, the paper examines the working of Corporate Social Responsibility practices in 10 Islamic banks and 10 Conventional banks.

Findings:-The results show positive \& little significant difference in the level and the degree of the disclosures between Islamic and Conventional banking. This difference is due to expose of IFIs by religious Islam.

Originality/value: - This paper's contribution to the literature shows the actual difference of CSRD by comparing disclosures between Islamic and Conventional banking. The paper shows the level of pressure of Islamic concepts and beliefs on CSRD in Islamic banking.

Keywords: - Corporate Social Responsibility, Disclosure, Islam, Financial institutions, Islamic Banking, Conventional banking.
\end{abstract}




\section{Introduction}

CSR is great social and legal responsibility provided by banks, however this service is more related to Islamic banks. It shows friendly and kind behavior of organization for its employees and customers. It is called ethical investment because it increases the positive impacts of an organization. CSR can influence the whole society, as it is related to social and moral values. CSR is used to incorporate social and environmental policies to improve their relationship with stakeholders. It is the obligation of banks to provide social justice to their customers. CSR prefers social norms and ethical values on profit. So CSR practices inhabit the profit (Manuel and Lucia, 2007). It is considered as a competitive edge for organizations (Branco and Rodrigues, 2006). People perceived that CSR provides good governance, employee's rights, proper education and training. Corporate responsibilities include relationship of banks with people, stakeholders and other communities. Banks may loss their investments by following CSR, because it restraints unethical investments (Reyes 2002). CSR is most forceful, complicated and exigent sector in banks (Gustafson, 2006). In addition, CSR also works for the welfare of the society (Osho, 2008). Banks can influence their environment positively by implementing CSR (Ogungbayi, 2009). In return, CSR helps to carry business, which is relevant to environmental conditions (Ajala, 2009). Another important factor of CSR is that it shows the relationship of banks to the society (Akinloye, 2009), and includes social, economic, ethical and unrestricted responsibilities (Archie, 1979). Corporate Social Responsibility is concerned with managers and accountants, as it is related to the profit of organization. CSR helps to measure the interdependent relationship between banks and economic system. CSR works for social welfare more than the interest of firm and legal requirements. It follows Islamic rules of Shariah, which provides social independency to common people. It prohibits illegal banking, so it is implemented in Islamic banks all over the world. Therefore it is more logical to say that CSR is obligation of banks to manage their social, economic and environmental activities at local and global level. CSR was introduced in late 1960s and early 1970s. CSR provides financial and non-financial information regarding social culture of organization (Guthrie and Mathews, 1985). CSR has become widely used research area for last few decades. The purpose of Islamic banking is to provide social justice without any exploitation (Usmani (2002, p. 113). In Islamic countries, government normally supports the implementation of CSR (Sharani, 2004; Yunus, 2004). Accounting and Auditing Organization for Islamic Financial Institutions support the development of CSR (Sharani, 2004; Yunus, 2004). A Number of Islamic banks are not working according to the rules of Shariah (Usmani, 2002). This research paper is an addition to the existing knowledge of CSR. The present study tests the relationship of different determinants with CSR. These determinants are; social disclosure, economic development, corporate governance, zakat deduction, social justice, accounting policies, and new channels of investment. Most of the determinants are related to Islamic rules, so they are implemented in Islamic banking. . Purpose of this Research paper is to analyze the comparative study of CSR in Islamic and Conventional banking. 


\section{LITERATURE REVIEW}

In Islam, social justice plays a vital role in developing a society. It is clearly said in Holy Quran, "We send our Messengers with clear signs and sent down with them the Book and the Balance (Right and Wrong), that men may stand forth in justice" (The Holy Qur'an S57:25). CSR practice in relation to Islam emphasizes on the theme of Islamic values such as social justices, balanced life, and human well being with providing the basic requirement of human needs (Chapra, 1992). In Islamic business point of view, everyone is accountable in front of GOD about his responsibility towards humanity (Haniffa and Cooke, 2001). Islam is based on all aspects of life. It not only concerned with individuals but also give guide line for social responsibilities and business matters (Tinker, 2004). The basic part of Islam is based on social justice and economic stability which have no limits (Ebrahim and Joo, 2001). For the social accountability in the society, Islam introduced the system of zakat and donations from both individuals and business groups, so that there may create balance between the distribution of wealth between rich and poor (Lewis, 2001). CSR practices are basically introduced to provide the social justices to the society (Gray et al., 1987). Islam is a combination of all the aspects of society either political, legal, community welfare or social justice. All Islamic values about human life either individual or business are stated in Holy Quran and Sunnah (Rice, 1999). Socio-economic justice is necessary for Islamic banking. The main purpose of Islamic socio-economic order is to bring fair laws and justice in society (Ebrahim and joo, 2001).In Islam it is said that there is no discrimination with anyone. So the main aim of Islamic Shari'a is to provide the safety, security and justice to people for their belief, life, wealth and prosperity equally (Kalma, 2005).Islamic banking system helps the poor people by providing them resource of income instead of charity funds (Agawall and yousaf, 2000; Hassan, 1995).

Social disclosure in Islamic banking is required for social justice and accountability. Islamic banks were mainly established to avoid misuses of social justice and distribution of wealth (Usmani, 2002). In accordance with Islamic rules, dealings of company cannot contradict societal and moral values (Usmani, 2002). Islamic banks are confident and optimistic for implementation of CSR (Sharani \& Yunus, 2004).

New channels of investments and financing strategies are adopted by Islamic banks (Usmani, 2002). This will help to improve economic standard of small businessmen. Profit and loss sharing (Musharkah) is adopted in Islamic banks (Usmani, 2002). Some Islamic banks are not focusing on social and moral values of Shari'ah (Usmani, 2002). All organizations have right to follow their personal interest and objectives related to social surroundings (William, 1999). To gain the trust of people, Islamic banks should follow Shari' ah (Baydoun and Willett, 2000). Stakeholders, political economy and authorities define that companies and individuals are linked with society (Ramanahthan, 1976; Deegan, 2002; William, 1999). Therefore, organizations should be aware that either they are working under social values or not (Deegan, 2002). CSR is related to organization's action for the prosperity of society (Bowman and Haire, 1976). Financer and managers are responsible for all business activities (Lewis, 2001).

According to Quran and Sunnah, organizations should perform dealings according to 
economic and social honesty, such as charity, Musharkah, interest free loan and zakat (Sadeghzadeh, 1995).

Islam does not allow any illegal or unfair division of wealth because it focuses on social and economic honesty. If Islamic banks want authority for their survival, significant knowledge about CSR should be revealed by them (Sadeghzadeh, 1995). Social disclosure depends on number of residents in particular region and, social and political environment (William, 1999; Newson and Deegan, 2002). As public independence and liberty is associated with political rights, it will restrict social disclosure (William, 1999). It increases the restriction on business activities by concerned government (Gastil, 1891). Islamic banks working in social and political liberties can easily reveal CSR (William, 1999). So a negative relationship exists between CSR disclosure and, public and political domination. If size of population is large in concerned society, it will definitely influence CSR disclosure. Number of people decides the level of CSR activity. If Islamic bank depends on financial help from public, it will be answerable to society for CSR practices (Newson and Deegan, 2002). Islamic banks are more answerable for social disclosure irrespective of local principles because they are answerable to Islamic society (Maali, 2007). CSR disclosure in Islamic banking is affected by the authority of people (Karim, 1990). In case of large number of people in concerned area, a competitive stress will be created on Islamic banks to retain their authority (Roberto, 1992).

Bank manager is negotiator for both stakeholders and Mudaribs. Islamic banks do not allow profit earning on their actions performed under Shari'ah (Usmani, 2002). Many Islamic banks are using Islamic Governance, which holds strict supervision in order to control the disagreement of interest between Mudaribs and managers of banks. SSB controls any innovations in Islamic banking rules. SSB is not compulsory for banks. It evaluates either banks are working according to principles of Shari'ah (Baker, 2002). In last 30 years, Islamic banks have flourished a lot. But, they should obey rules of Shari'ah, as they are revealing less information than is required from them.

Ethical values of Islam depend upon humanity, social welfare, check and balance, and equal rights that are the basics of brotherhood and all types of human needs. Islamic ethical values also provide equal importance to the customers and stakeholders by providing fair and best services. Islam provides a society which is based on justice that is free from exploitation (Usmani, 2002). The freedom of every individual is important in Islam. Neither it exploits the rights of others, nor it has any controversy against societal benefits of Islamic society. Private ownership is also an ethical right of Islam because according to this right everyone can transfer his property (chapra, 1992). All the employees and boss have equal rights and they are answerable to someone e.g. in Islam all the caliphs and their followers along with the employees were answerable to Allah Almighty (Hamid et al,1993; lewis,2001).Everyone has equal opportunity to utilize the resources to create maximum yield according to Allah's guidance to maintain the welfare and justice in society(Metwally,1997).IFIs provide the equal opportunity of training, development and advantages to employees. IFIs avoid from negative issues on work place and emphasize on positive behavior toward employees and stakeholder. Basic Islamic values are Zakat and charity, because these social values reduce the difference $\mathrm{b} / \mathrm{w}$ rich and poor. Due to these activities circulation of wealth increases which in turn reduces 
the gap (Lewis, 2001). Zakat and charity also support the education, Health and social welfare. But all these values are not found in conventional banking. So Islamic banking system and CSR have more resemblance as compared to conventional banking. Riba (interest) is prohibited in Islam, so Islamic banks provide interest free loans which mean no return to debtor. Interest is wealth that is gained without any effort so it is not permissible in Islamic banking (Mirza and baydoun, 2000).Prophet Muhammad (S.A.W) strictly forbid the all forms of interest in his last pilgrimage speech (Ahmed and Hassan, 2007).To enhance the social welfare and ethical investment, IFIs work on the bases of prohibition of interest and profit and loss sharing. It means if creditor faces the loss/profit, debtor also have equal sharing or sharing according to the contract in loss/profit (Llias, 2008). This mode of financing is only found in Islamic banking. Zakat is the back bone of Islamic banking. It is collected from rich people and is distributed among the needy people. Muslims business rules are based on of shari'ah, because they have special social purposes (Haniffa and Hudaib, 2007). Conventional banking concentrates only on their own interest saving (William, 1999). But Islamic banking preserves the rights of the individuals (Sadeghzadeh, 1995). Islamic micro financing scheme means programs which are introduced for the purpose of extending small loans to a very poor people to achieve self employment projects which generate income for them and their families (Microcredit Summit,2004). The world bank organized this program to reduce income inequalities and poverty.

Mudarabah is one of the micro financing schemes in which capital provider or microfinance institution (rabbul Mal) and small entrepreneur (mudarib) becomes a partner. Profits are shared by both parties but loss bears only one capital provider Muzara'ah is a form of mudarabah contract in which micro finance institutions provide land or monetary capital for farming products in return or sharing of harvest on the basis of agreed profit sharing ratio. Capital provider needs a large amount of capital and has to manage risk involved in it. MUSHARAKAH FINANCING is a micro financing technique in which microfinance institutions enter in the partnership with micro-entrepreneurs. If there is profit, it will be decided on the basis of pre-agreed ratio but if there is a loss it will be shared on the basis of capital contribution margin. MURABAHAH FINANCING is a mode of micro-finance in which micro-finance institutions requires to acquire and purchase assets or business equipment and then sell that asset to the entrepreneur at mark up. It is a more practical and suitable scheme in micro-financing. IJARAH FINANCING is a long term contract of rental subject with particular conditions of Shari'ah. In it micro-finance institutions purchase the asset first and then offer the customer for lease and institute is responsible for risk involved in assets. QARDHUL HASAN means interest free loan. These loans are called beautiful loans in Arabic. That loan is given to any person with the intentions that he or she gives money to someone who is too poor and can't take money back from him if he/she only wants to please Allah by this act (Mirakhor and Iqbal, 2001).

Verbal meaning of Zakat is to grow and to increase anything (Qardhawi, 2000). Zakat means to purify and clean anything from rubbish or dirt. It is a spiritual way of purifying something like money. Nobody's wealth can be purified even though he will not fulfill the rights of other 
people whatever Allah gives him in excess(Maududi,1988). The main purpose of giving zakat is to satisfy Allah who gives us every thing

Islam is a religion of Muslims and they have to follow the terms and conditions of Islam. Islam gives the concept of zakat. Zakat means the transfer of ownership from one individual to another under certain conditions. Zakat is one of the basic five pillars of Islam. It is the duty of Muslims to give the payment of Zakat. The eight beneficiaries are mentioned in the Quran (Surah At-Touba; 60). Zakat is given to those people who need it. Zakat purifies money and increases it continuously. Allah likes those people who fulfill his orders and bestows them more.

It is the main objective of payment of Zakat. By paying zakat favorable effects may occur in aggregate consumptions, savings, investment, aggregate supply of labor and economic growth .In Zakat institutions, efficiency means that how well company is using their resources for meeting the objective of socio-economic justice. Governance means a process or a complete structure of managing and directing the affairs of zakat intuitions. It is required to check that needy people get the payment of Zakat. These institutes are specially designed for the social welfare of any country. The pleasure of Allah is utmost important for Muslims. We must always try to fulfill orders of Allah.

According to Shariah, Islamic economics system has strict Islamic principles; all the business and financial transactions are free from Interest, all the goods, trades, services are Halal according to Islamic point of view, transactions which have high uncertainty may result to financial loss and payment of zakat which is very important Islamic economic system consists of both profit and non- profit financial institutions. Profit financial institutions are those which generate profit through business like banks and Insurance firms. On-profit financial institutions are those which do not generate profit like zakat institutions, Baitulmal etc. Zakat institutions are directly related to the economic system (Khan, 1995). Muslim countries considered zakat as a peripheral system not as a main part of fiscal system. Taxation is considered as an important part of fiscal system. Zakat is a voluntary system which means that it is not compulsory whoever wants to pay money(Baker and Rehman,2007). Modern Islamic institutions have more focus on wealth generating institutions like Islamic banks and Islamic Insurance etc and little focus on wealth distribution institutions like zakat institutions.

Islam encourages people to earn and make their lives comfortable. Muslims have to follow rules of Quran that is their first duty. Allah always reminds Muslims to make a balance between world life and hereafter. Socio-economic justice is the main objective of zakat and it can be achieved when there is a balance between mechanism of wealth creation and wealth distribution. Proper distribution of zakat is very necessary for the development of any country. Zakat is used for the purpose of increasing savings and avoids cautious savings like hoarding (Choudhury, 1983).Effect of Zakat on savings depends on nature of consumption on which society believes (Metwally, 1986). Zakat reduces poverty which is one of the major problems faced by the society. Islam encourages rich people to invest their money on poor people then poverty reduces and employment and productivity increases. Its mutual responsibility to help others in time of need, is actually a basic concept of Islam (Afzal, 1980) 
Islamic banking system introduced new ways of financing loans and opened new channel of investing money which led the country to the path of development (Usmani, 2001). In his later paper, he says that the permitted ways of financing in Islamic banks are not banned according to the laws of Quran and Sunah (Usmani, 2002). IFIs not only mean the responsibilities towards human as religion obligation but also as financing body (Farook, 2008). The corporate social performance is the main issue for increasing interest in the business world (Caroll, 1991 Griffin And Mahon, 1997). There has been a various measures that control the organizational functions busy in a larger set of stakeholders and lining beside the large options of inputs, processes internally and then provide results (Waddock And Graves, 1997; Wood, 1991).

Generally this paper provides the information about CSR strategies and etc. The analysts provide information to others, the analysts is the middleman between the firms , CSR strategies and the capital market. The CSR behave to create respect for firms for long time then these values create investment suggestions for the analysts (Margolis, Elfenbein And Walsh, 2007).

First reasons tells that if long term financial performance affects CSR by operating the value for the biggest line of stakeholders , customers , employees , and competitors . the outputs should bring changes in financial performance and directly impact on analysts suggestions . Secondly , multidimensional funds are invested in socially responsible firms, in this way there is increase in demand for analysts, who can understand the CSR strategies . Thirdly the CSR increases the stock price. This increase is due to the substantial values of funds, that for investment in CSR. This will also affect the analysts suggestions if the amount of funds is large. In return, investors take pressures on the stock price of these companies that qualify as corporate social responsibility. In these conditions the demand curve for these stocks will shift downward, that is why there is elasticity in the demand curve (Shleifer, 1986; Coval and Stafford, 1999).

In Islamic banking system corporate governance is increasing in size due to ethical values which attract the customers and stake holders. But some papers show the Islamic banking system has deficiency of empirical analysis. The most important and latest term which is mostly discussed about Islamic banking is corporate and shari'ah governance. Strong corporate governance increases the transparency, honesty and responsibilities within the whole organization and among all the stakeholders. Shari'ah governance is necessary for Islamic banking for creating and maintaining the confidence of all the stakeholders and shareholders in all activities of banking (Hasan and Hassan, 2011). Islamic banking needs more corporate governance to omit the weaknesses of the past and to increase the transparency by monitoring the financial activities (Archer et al, 1998). Islamic banks governance is dependent on ethical values. But the gap of communication is so high $b / w$ Islamic banks that it affects negatively on Islamic governance. Ethical identity means mission and vision of organization should be clear. 
Top management should be co-operative. Organization should be society oriented (Haniffa and Hudaib, 2007).The corporate governance in Islamic banking is based on monitoring level. As the monitoring level about investment is increasing according to the shari'ah rule, it will also increase the corporate governance. Social and political environment, right and responsibilities also affect the corporate governance because it affects the efficiency of the organization.

Governance of Islamic banks is monitored by Shari'ah board. The employees of Islamic banks have a unique skill to monitor the riba conflict $\mathrm{b} / \mathrm{w}$ management of bank and stakeholder (Karim, 1995). Inside corporate mechanism also have an important role for progress of the organization (Ho and Wong, 2001). Sound inside governance mechanism provides to an organization more success and enhance the organization image. When the SSB members increase, they increase the CSR revealing that will ultimately increase the monitoring abilities. It is basic demand in several Islamic banks. Islamic banking requires more revealing of CSR information. So all the members of SSB give the ideas and implement the Islamic laws in better way (AAOIFI, 2003). Communication b/w the corporate members and SSB member is also a source of revealing the CSR information (Dahya et al, 1996). Training of Shari 'a supervisory board members also increase the corporate governance and develop a better image of Islamic banking. Communication with customer has positive effect on the image of the organization that is increase performance/governance of the corporation. Top members of the management also play important role in creating the image of the organization (Lee's, 2004). Clean status of the Islamic banking is also a reason of its good image and to attract the customers because it has interest free loan techniques like in Saudi Arabia (shook and Hassan,1988; Zaher and Hassan, 2001). Stability in transactions is also a reason of its good image and has effect on its governance (Rose and Thomsen, 2004). Mostly commercial banks follow the principles of Islamic banking system due to its good image among the customer (Zaher and Hassan, 2001).The TOP management of an organization has great role to develop the image of the organization like Malaysian banking sector has a unique image among their customer due to its management. Because it's CEO has good ethics with his customers. Good ethics also effect the customer's perception (Grunig, 1993).

Economic development can be seen through increasing number of well being people. People having good jobs are sign of economic development as they are not dying due to poverty. Their life style is improving. CSR is closely related to economic development in wider way. CSR is providing justice and social equality to the society. CSR is contributing to sustainable and prosperous society. To see what CSR is actually contributing to the society, some overstatements should be avoided. CSR is working against the violation of employee's rights. Organizations, in which there is far-reaching supply chain and large number of visiting customers, CSR is not working properly. Only in extensive industries where customers are aware of human rights, CSR practices are widely used. Destruction of basic rights of workers restricts the authority of CSR for development. CSR cannot substitute government, because in case of privatization, CSR cannot provide basic rights. Workers' rights are confined through cooperative bargaining. A social equivalent is required to confine employee's rights by rules of governing bodies. A social consideration is required between government and social associates for Global social contract. Impact of CSR can be checked by role of government in confining 
rights of employees. CSR is working properly in those countries where labor rules are imposed. These rules are mostly imposed in democratic countries. NCP's are setup by government to provide guidelines to CSR. These guide- lines can be considered as standard. For instance a contract between government and IMF which needs to sell government assets and decrease wages can be refused by government to preserve its sovereignty.

It has arranged social dialogue between Global enterprises, which help to generate Global cooperative bargaining. ITS multinational firms made 10 contracts to help workers to arrange and improve themselves. Global social dialogues and contracts enable workers to determine solution of their problems. Productive employee's relation can be enhanced through situation developed by UN Global compact. Independent codes of conduct are also important aspects of CSR. For social audit firms, it provides significant services. Government and trade unions are not participating so freedom of relationship and cooperative bargaining might be ignored. It concludes that CSR is not actually protecting workers rights. Unilateral or independent code provides liberty to workers to speak for their fundamental rights. In CSR, trade union is providing self organization to workers. Sometimes it misguides about workers real demand. At workplace, it provides union to workers. New upcoming markets are providing equal opportunities as OESD (Baskin, 2006). There is a little difference between top companies ad newly set up markets for CSR activity level (Baskin, 2006). CSR helps in the development of power. Due to economic changes in developed countries, such as democracy, liberty and privatization causes the development of CSR (De Oliveira, 2006). Purpose of CSR is to solve the problem of unemployment, unequal distribution of wealth and corruption in banking (De Oliveira, 2006). Multinational investments provide social benefits (Gabrial, 1972).

Now SRI is also determining the role of CSR. CSR is helping to seek FDI for developing countries.

Global instructions are promoting economic development. CSR is making environment that cause economic equality. It focuses on investment and saving to generate jobs and human capital (Nelson, 2003). When a country depends on international financial institutes for its economic prosperity, its government has to compromise on its moral and social values. CSR in developing countries is a fabulous opportunity to provide knowledge of CSR.

The corporate social performance is the main issue for increasing interest in the business world. There have been various measures that (Carroll, 1991; Griffin and Mahon) control the organizational functions which engage in a larger set of stakeholders and lining beside the large options of inputs, processes internally and then provide outputs. (Waddock and Grave, 1997; Wood, 1991). The importance of CSR information is attached to the impact of analysts, results and outcomes of customers to impact of their recommendations. The work of finance and accounting creates important role for analysts in the capital market. CSR strategies explain various reasons that affect the marketing approaches of analysts. First of all, if long term financial performance affects CSR by operating values for the line of stakeholders, customers, employees and competitors, the results should be changed in financial performance and directly impact on analyst's suggestions. Secondly, various funds are invested in socially 
responsible firms to create increase in demand analysts. Thirdly, the upcoming CSR increase in the stock price is due to the substantial values of funds. This will also affect the analyst's suggestions. If the amount of funds is large, the investors take pressure on the stock price of those companies which qualify and are socially responsible. In these conditions the demand curve for these stocks will shift downward due to which there is elasticity in demand curve (Shleifer 1986; Coval and Staffors). Finally there is increase in demand for providing information related to the CSR strategies or to the investment community.

\section{HYPOTHESIS GENERATION:}

H0: There Is No Significant Relationship Between CSR Practices And Islamic Banking.

H1: There Is A Significant Relationship Between CSR Practices And Islamic Banking.

H0: There Is No Significant Relationship Between CSR Practices And Conventional Banking.

H1: There Is A Significant Relationship Between CSR Practices And Conventional Banking.

\section{SUB HYPOTHESIS:}

H0: There is no significant relationship between CSR practices and Social Justice and Accountability.

H1: There is a significant relationship between CSR practices and Social Justice and Accountability.

H0: There is no significant relationship between CSR practices and Social Disclosure.

H1: There is a significant relationship between CSR practices and Social Disclosure.

H0: There is no significant relationship between CSR practices and Ethical value of Islam.

H1: There is a significant relationship between CSR practices and Ethical value of Islam.

HO: there is no significant relationship between CSR practices and New channels of investment.

H1: There is a significant relationship between CSR practices and New channels of Investment.

H0: There is no significant relationship between CSR practices and Corporate governance.

H1: There is a significant relationship between CSR practices and Corporate governance.

H0: There is no significant relationship between CSR practices and payment of Zakat.

H1: There is a significant relationship between CSR practices and Payment of Zakat. 
H0: There is no significant relationship between CSR practices and Economic development.

H1: There is a significant relationship between CSR practices and Economic development.

H0: There is no significant relationship between CSR practices and Financing policies.

H1: There is a significant relationship between CSR practices and Financing policies.

\begin{tabular}{|c|c|c|c|c|c|c|c|}
\hline \multirow[b]{2}{*}{ VARIABLE } & \multirow[b]{2}{*}{ Sample Size } & \multicolumn{3}{|c|}{ CONVENTIONAL BANKING SET UP } & \multicolumn{3}{|c|}{ ISLAMIC BANKING SETUP } \\
\hline & & Mean Value & S.D. & Variance & Mean Value & S.D. & Variance \\
\hline Gender & 100 & 1.34 & 0.47851812 & 0.229 & 1.26 & 0.44309 & 0.196327 \\
\hline Zakat Deduction & 100 & 2.46 & 0.88548384 & 0.784 & 1.52 & 0.57994 & 0.336327 \\
\hline $\begin{array}{l}\text { Encourage New } \\
\text { Channels of } \\
\text { Investment }\end{array}$ & 100 & 1.92 & 0.75159694 & 0.565 & 1.76 & 0.51745 & 0.267755 \\
\hline $\begin{array}{c}\text { Working } \\
\text { Satisfactory for } \\
\text { Social } \\
\text { Disclosure }\end{array}$ & 100 & 2.06 & 0.79308234 & 0.629 & 1.92 & 0.77828 & 0.605714 \\
\hline $\begin{array}{l}\text { Focus on Ethical } \\
\text { Values of Islam }\end{array}$ & 100 & 2.64 & 1.04510521 & 1.092 & 1.7 & 0.67763 & 0.459184 \\
\hline $\begin{array}{l}\text { Implementation } \\
\text { of Microfinance } \\
\text { Schemes }\end{array}$ & 100 & 2.72 & 0.78350338 & 0.614 & 2.38 & 0.94524 & 0.893469 \\
\hline $\begin{array}{c}\text { Economic } \\
\text { Development of } \\
\text { Society }\end{array}$ & 100 & 1.98 & 0.84491275 & 0.714 & 1.86 & 0.49528 & 0.245306 \\
\hline Working of CSR & 100 & 2.38 & 1.12286078 & 1.261 & 2.08 & 0.66517 & 0.442449 \\
\hline $\begin{array}{c}\text { Social Justice } \\
\text { Towards } \\
\text { Customer }\end{array}$ & 100 & 2.22 & 0.93219075 & 0.869 & 1.98 & 0.58867 & 0.346531 \\
\hline $\begin{array}{l}\text { Working of } \\
\text { Corporate } \\
\text { Governance }\end{array}$ & 100 & 2.62 & 0.667 & 0.444 & 2.24 & 0.771 & 0.594 \\
\hline
\end{tabular}

\section{Results \& Discussion:}

This report is about the working of CSR practices in Islamic banking and conventional banking. In the present study, questionnaires are filled from the employees of Islamic and 
conventional banking and check the results. Here are the results of 50 questionnaires for Islamic banks and 50 questionnaires for Conventional banks. These are the comparative results of both banks. Details of these calculations are given below:-

First variable is Zakat deduction. Here results are interpreted on the basis of three values:-Mean S.D and Variance. For Conventional banks, Mean value is 2.46, S.D 0.89 and Variance is 0.784 . For Islamic banks results are slightly different like, Mean value is1.5, S.D is 0.58 and Variance is 0.34 . It shows that in Islamic banking there is little variation in values as compare to Conventional banking. There is strong positive relationship of CSR practices with Zakat deduction in Islamic banking as well as in Conventional banking positive relationship is found. Therefore we accept H1.

Second variable is to encourage new channels of investment. Here results are interpreted on the basis of three values:-Mean S.D and Variance. For Conventional banks, Mean value is 1.92, S.D 0.75and Variance is 0.56 . For Islamic banks results are slightly different like, Mean value is 1.76 , S.D is 0.52 and Variance is 0.27 . There is strong positive relationship of CSR practices with new channel of investment in Islamic banking. Similarly in Conventional banking there is positive relationship. Therefore the researchers accept $\mathrm{H} 1$.

Third variable is working satisfactory for social disclosures. For Conventional banks, Mean value is 2.06 , S.D is 0.79 and Variance is 0.629 . For Islamic banks results are slightly different like Mean value is 1.92, S.D is 0.78 and Variance is 0.606 . There is strong positive relationship of CSR practices with social disclosures in Islamic banking as well as in Conventional banking. Therefore we accept H1.

Fourth variable is Focus on ethical values of Islam. For Conventional banks, Mean value is 2.64, S.D is 1.05and Variance is 1.092. For Islamic banks results are slightly different like, Mean value is 1.7, S.D is 0.68 and Variance is 0.46 . There is strong positive relationship of CSR practices with ethical values of Islam in Islamic banking as well as in Conventional banking. Therefore we accept $\mathrm{H} 1$.

Fifth variable is Implementation of microfinance scheme. For Conventional banks, Mean value is 2.72 , S.D is 0.7835 and Variance is 0.614 . For Islamic banks results are slightly different like, Mean value is 2.3, S.D is 0.945 and Variance is 0.89 . There is positive relationship of CSR practices with Implementation of microfinance scheme in Islamic banking as well as in Conventional banking t. Therefore we accept H1.

Sixth variable is Economic Development of society. For Conventional banks, Mean value is 1.98 , S.D is 0.84 and Variance is 0.71 . For Islamic banks results are slightly different like, Mean value is 1.8, S.D is 0.49 and Variance is 0.24 . There is strong positive relationship of CSR practices with Economic Development of society in Islamic banking as well as in Conventional banking. Therefore researchers accept H1.

Seventh variable is working of CSR. For Conventional banks, Mean value is 2.38, S.D is 1.2 and Variance is 1.21. For Islamic banks results are slightly different like, Mean value is 2.08, S.D is 0.66 and Variance is 0.44 . There is strong positive relationship of CSR practices in Islamic banking as well as in Conventional banking. Therefore we accept H1.

Eighth variable is social justice towards customer. For Conventional banks, Mean value is 2.22, S.D is 0.93 and Variance is 0.86 . For Islamic banks results are slightly different like, Mean value is 1.98 , S.D is 0.58 and Variance is 0.34 . There is strong positive relationship of 
CSR practices with social justice towards customer in Islamic banking as well as in Conventional banking. Therefore we accept $\mathrm{H} 1$.

Ninth variable is working of cooperate governance. For Conventional banks, Mean value is 2.62, S.D is 0.66 and Variance is 0.44 . For Islamic banks results are slightly different like, Mean value is 2.24, S.D is 0.77 and Variance is 0.59 . There is positive relationship of CSR practices with working of cooperate governance in Islamic banking as well as in Conventional banking. Therefore we accept H1.

\section{Conclusion:}

The above result of content analysis shows two remarkable clarifications. First, CSRD is presently most common practice between financial institutions. In most of those disclosures there were little differences between Islamic and Conventional banking. Secondly Islamic banking sector works under this point of view that they are accountable before GOD. Some additional research shows that there is great influence of Islam on CSRD in Islamic Banking. This also raises the thought that either other religious beliefs (e.g. Buddhism \& Christianity etc) also play an important role in CSRD.

Hence, from the complete research work conclusion was made that corporate social responsibility has been introduced in Islamic banking earlier than conventional banking. Because CSR practices are mostly related with the Islamic terms like social justice, accountability, deduction of zakat, microfinance schemes and adopting ethical values of Islam. But now conventional banking introduced CSR practices in their institutions. The data obtained from the questionnaires show that Islamic banking reveals more positive result as compared to conventional banking. However, the limitation of this study was that the sample was restricted to Bahawalpur region only. The findings of the study can be more expanded and generalized if research could be made all over the Pakistan.

From last two decades Islamic banking has become more accepted and more familiar in Islamic countries. So now people have more awareness about CSR practices in Islamic banking and about all other aspects of Islamic banking. Islamic banking provides more services according to the expectations of the people as compared to Conventional banking because Islamic banking is driven by economic realities. Governance of Islamic banks is better across the world. Like in Malaysia, Saudi Arabia and so many other countries, it is recommended by many researchers that there are so many factors that control CSR practices including socio-economic justice, ethical values, corporate governance etc. Socio-economic justice provides equal rights to every citizen. Results also showed that Islamic banking required more skillful and independent Shari'a board and advisory members. So that standardized accounting rules may be executed in all over the world. Conventional banking also executes the CSR practices but not properly. So Conventional banking also required focus on corporate governance, ethical values and all other factors discussed above about banking, so that they can overcome the drawbacks. Socio-political factor is most important for Conventional banking. Conventional banking should make possible donations and interest free loans to make their reputation more positive. Last but not least, further studies on the above discussed factors can 
provide more knowledge about Islamic and Conventional banking to ensure the CSR practices in both types of banking.

\section{References}

Afzal, O. (1980), “The social security of Islam”, in Zaman, M.R. (Ed.), Some Aspects of the application of stakeholder theory", Accounting, Organizations and Society, And Islam, Ph.D. Dissertation, University of Wollongong.

AJALA, V.O. (2005), "Public Relations: in search of professional Excellence": $2^{\text {nd }}$ edition, MayBest Nigeria Limited Ibadan, Pp203-204

Bakar, M.D. (2002), “The Shari'a supervisory board and issues of Shari' a rulings 103-127 Bakar, N.B.A. and Rahman, A.R.A. (2007), "A comparative study of zakah and modern taxation", Banking and Insurance, London, pp. 18-20.

Baskin, J. 2006. 'Corporate Responsibility in Emerging Markets'. Journal of Corporate Citizenship, 24, winter: 29-47.

Baydoun, N. and Willett, R. (2000), "Islamic Corporate Reports", Abacus, Vol. 36,

Bowman, E.H. and Haire, M. (1976), "Social Impact Disclosure and Corporate. Campbell, D.J 2000, "Legitimacy theory or managerial reality construction?

BRANCO, MANUEL CASTELO AND RODRIGUES, LÚCIA LIMA (2007): Issues in Corporate Social and Environmental Reporting Research: An Overview, in: Issues in Social \& Environmental Accounting 1 (1), pp. 72-90.

Business. Journal of Corporate Citizenship, 21 springs: 17-20.

Carroll, A. B. 1991. 'The Pyramid of Corporate Social Responsibility: Toward the Moral Chapra, U. (1992), Islam and the Economic Challenge, the Islamic Foundation, Leicester. Choudhury, N. (1983), "Aggregate demand and al-Zakat", Thoughts on Economics, Vol. 4 No. 9, disclosures- a theoretical foundation", Accounting, Auditing and Accountability.

Deegan, C. (2002), "The legitimizing effect of social and environmental pp. 1-8

Ebrahim, M. and Joo, T. (2001), "Islamic Banking in Brunei”, International Journal Social Economics, Vol. 28 No. 4, pp. 314-37.

Economics of Zakat, American Trust Publications, Indianapolis, IN, pp. 173-8 economy", Humanomics, Vol. 2 No. 2, pp. 43-55

ExxonMobil'. Development, 47(3): 69-77

Farook, S. (2008), "Social responsibility for Islamic financial institutions: laying down a framework", Journal of Islamic Economics, Banking and Finance, Vol. 4 No. 1. Freedom House, New York.

Gambling, T.E. and Karim, R.A.A. (1986), "Islam and 'Social Accounting",, Gambling, T.E. and Karim, R.A.A. (1991), Business and Accounting Ethics in Islam, 1 Gastil, R.D. (1981), Freedom in the World: Political Rights and Civil Liberties Gray, R., Owen, D. and Maunders, K. (1987), Corporate Social Reporting: Accounting and Accountability, Prentice-Hall, London.

Haniffa, R.M. and Cooke, T. (2001), Corporate Social Reporting in Malaysia: Impact of Culture and Corporate Governance Structure, Discussion Paper in Accounting and Finance, University of Exeter, Exeter.

J.KAU: Islamic Economics, Vol. 20 No. 1, pp. 25-40. 


\section{Macrothink

Journal of Business Ethics, 39(3): 297-318.

Karim, R.A.A. (1990), "The independence of religious and external auditors: The case of Islamic banks", Accounting, Auditing, and Accountability Journal Vol.

Khan, M.F. (1995), “An overview of the financial system of Islam”, Essays in Islamic Economics,

Lewis, M. (2001), “Islam and accounting”, Accounting Forum, Vol. 25 No. 2, pp. 103-27.

Maali, B., Casson, P. and Napier, C. (2003), Social Reporting by Islamic Banks.

Management of Organizational Stakeholders'. Business Horizons, 34: 39-48.3: De

Oliveira, J. A. P. 2006. 'Corporate Citizenship in Latin America: New Challenges to Maududi, A.A. (1988), Maashiaati Islam, Islamic Publication, Lahore.

Metwally, M.M. (1986), "The effect of the religious tax of zakah on investment in an Islamic Banking”.

Mirakhor, A. and Iqbal, Z. (2007), 'QQard hasan microfinance', New Horizon, Institute of Islamic No. 1, pp. 71-90. 384 Farook and Lanis.

Mr. Jim Baker. Adler, P.S. (2002): Investment'. Journal of Corporate Citizenship, 13(1): $145-63$.

Newson, M. and Deegan, C. (2002), "Global expectations and their association Journal of Business Finance and Accounting, Vol. 13, No.1, pp. 39-49.

Qardhawi, Y. (2000), Fiqh Al Zakat A Comparative Study of Zakat, Regulations and Philosophy in Series, Kluwer Law International, Amsterdam.

Ramanathan, K.V. (1976), "Toward a theory for corporate social accounting",

REYES CID (2002) Education-focused Corporate Social Responsibility in El Salvador; World Bank Technical Assistance Study, Washington D.C

Rice, G. (1999), "Islamic ethics and the implications for business", Journal for Business Ethics, Vol. 18 No. 4, pp. 345-58.

Roberts, R.W. (1992), "Determinants of corporate social responsibility disclosure:

Sadeghzadeh, A. (1995), Social responsibility accounting, sustainability accounting with corporate social disclosure practices in Australia, Singapore and South.

Sharani, U.M. (2004), Corporate Social Responsibility Underlines Values Propagated by Islam, Bernama, Kuala Lumpur.

The Islamic Foundation, Leicester, pp. 77-87. The Light of Quran and Sunnah, Vol. 1, Scientific Publishing Centre, King Abdul Aziz

Tinker, T. (2004), "The enlightenment and its discontents: antinomies of Christianity, Islam and calculative science", Accounting, Auditing \& Accountability Journal, Vol. 17 No. 3, pp. 442-75. University, Jeddah (translated by M. Kahf)

Usmani, M.T. (2002), an introduction to Islamic finance Arab and Islamic Law And their harmonization in Islamic banking and finance" in Islamic Finance:

Usmani, M.T. (2002), an Introduction to Islamic Finance Arab and Islamic Law Series, Kluwer Law International, 